\title{
Influence of food consumption in the glycemic profile of children and adolescents with type 1 diabetes Mellitus
}

\author{
Influência do consumo alimentar no perfil \\ glicêmico de crianças e adolescentes \\ com diabetes Mellitus tipo 1
}

\author{
Camilla Kapp FRITZ1 ID 0000-0002-0288-2890 \\ Andreia Araújo Porchat de LEÃO' ${ }^{1}$ (ID) 0000-0002-8385-8007 \\ Márcia Regina Messaggi Gomes DIAS² (ID) 0000-0001-6158-2014 \\ Adriane de Andre Cardoso DEMARTIN| ${ }^{3}$ ID 0000-0002-6772-1940 \\ Suzana NESI-FRANÇA ${ }^{3}$ (ID) 0000-0002-3987-3998
}

\section{A B STR ACT}

\section{Objective}

To review the dietary intake of children and adolescents with type 1 diabetes Mellitus and its association with the glycemic profile.

\section{Methods}

Longitudinal observational study. Dietary intake was measured using a three-day dietary record and the glycemic profile with a continuous glucose monitoring (range between 70 and $180 \mathrm{mg} / \mathrm{dL}$ ) and serum glycated hemoglobin levels (ideal $<7.5 \%$ ). Anthropometric data, insulin therapy, and carbohydrate counting were collected.

\footnotetext{
1 Universidade Federal do Paraná, Departamento de Pediatria, Programa de Pós-Graduação da Saúde da Criança e do Adolescente R. Padre Camargo, n. 250, Alto da Glória, 80060-240, Curitiba, PR, Brasil. Correspondence to: C.K. FRITZ. E-mail: <camillakf.nutri@gmail.com>.

2 Universidade Federal do Paraná, Curso de Nutrição, Departamento de Nutrição. Curitiba, PR, Brasil.

${ }^{3}$ Complexo Hospital de Clínicas da Universidade Federal do Paraná, Departamento de Pediatria, Unidade de Endocrinologia Pediátrica. Curitiba, PR, Brasil.

Support: Conselho Nacional de Desenvolvimento Científico e Tecnológico (CNPq, Brazilian National Council for Scientific and Technological Development) (Process n. 487557/2013-).

Article elaborated from dissertation by C.K. FRITZ, entitled "Associação entre o consumo alimentar e exercício físico no controle glicêmico de crianças e adolescentes com diabetes mellitus tipo 1". Universidade Federal do Paraná; 2018.
}

How to cite this article

Fritz CK, Leão AAP, Dias MRMG, Demartini AAC, Nesi-França S. Influence of food consumption in the glycemic profile of children and adolescents with type 1 diabetes Mellitus. Rev Nutr. 2020;33:e190220. https://doi.org/10.1590/1678-9 $865202033 e 190220$ 


\section{Results}

The sample included 34 individuals with type 1 diabetes Mellitus aged 13.6 2.1 years. The majority of the population was eutrophic (76.4\%). The entire sample used the basal-bolus insulin regimen, with mean insulin dose of $1.0 \pm 0.2 \mathrm{U} / \mathrm{kg} / \mathrm{day}$; for $44.1 \%$ of the sample the carbohydrate counting method was used. Macronutrients intake was adequate in only $8.8 \%$ of the individuals, the highest frequency of inadequacy was related to carbohydrates $(p=0.07)$. Inadequate glycemic control with hyperglycemia episodes and high mean glycated hemoglobin $(9.7 \%)$ was observed in all individuals $(61.3 \pm 18.5 \%)$. Carbohydrate counting was responsible for maintaining the percentage of time that the patient had interstitial blood glucose values within the range $>40 \%$ $(p<0.001)$ and maintaining the percentage of time in hyperglycemia $<50 \%(p<0.001)$.

\section{Conclusion}

The majority of individuals were eutrophic, but presented inadequate dietary intake and glycemic control. The method of counting carbohydrates positively influenced the glycemic profile.

Keywords: Adolescent. Blood glucose self-monitoring. Child. Diabetes Mellitus, type 1. Food consumption.

\section{RE S U M O}

\section{Objetivo}

Analisar o consumo alimentar de crianças e de adolescentes com diabetes Mellitus tipo 1 e sua associação com o perfil glicêmico.

\section{Métodos}

Estudo observacional longitudinal. O consumo alimentar foi mensurado por meio de um registro alimentar de três dias, e o perfil glicêmico com um monitor contínuo de glicemia (alvo entre 70 e 180mg/dL) e de níveis séricos de hemoglobina glicada (ideal $<7,5 \%$ ). Foram coletados dados antropométricos, terapia insulínica e contagem de carboidratos.

\section{Resultados}

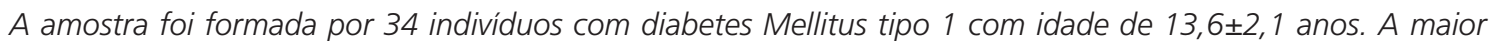
parte da população era eutrófica (76,4\%). Toda a amostra utilizava o esquema de insulina basal-bolus, com dose média de 1,0 0,2U/kg/dia, e 44,1\% realizava o método de contagem de carboidratos. O consumo dos macronutrientes estava adequado em apenas $8,8 \%$ dos indivíduos, sendo a maior frequência de inadequação nos carboidratos $(p=0,07)$. Foram observados controle glicêmico inadequado com episódios de hiperglicemia em todos os indivíduos $(61,3 \pm 18,5 \%)$ e média elevada de hemoglobina glicada $(9,7 \%)$. A realização da contagem de carboidratos foi responsável por manter o percentual de tempo em que o paciente obteve valores de glicemia intersticial dentro do alvo $>40 \%(p<0,001)$ e por manter o percentual de tempo em hiperglicemia $<50 \%(p<0,001)$.

\section{Conclusão}

A maior parte dos indivíduos era eutrófica, porém apresentava consumo alimentar e controle glicêmico inadequados. O método de contagem de carboidratos influenciou positivamente o perfil glicêmico.

Palavras-chave: Adolescente. Automonitorização da glicemia. Criança. Diabetes Mellitus tipo 1. Consumo de alimentos.

\section{INTRODUCTION}

According to the International Diabetes Federation, the prevalence of Type 1 Diabetes Mellitus (T1DM) is estimated to be between 0.3 to $0.4 \%$ of the world population and that by 2050 these numbers may triple. The incidence and early onset of this condition is of concern. Thus, adequate treatment and follow-up are essential [1,2].

Diet, insulin therapy and physical exercise form the main pillars for an ideal glycemic control, essential for an individual with T1DM to grow adequately with the prevention of diabetes complications 
[3]. It is known that nutritional monitoring favors glycemic control, promotes a reduction of 1 to $2 \%$ in the levels of Glycated Hemoglobin ( $\mathrm{HbA1c}$ ) and, when associated with the other components of diabetes care, improves the clinical and metabolic parameters of this disease [4]. The Carbohydrate Counting method is a food planning tool that has a proven influence on the improvement of glycemic control, in addition to allowing diet flexibility [5].

The composition of the diet recommended by the guideline of the International Society for Pediatric and Adolescents Diabetes (ISPAD) is based on recommendations for the healthy population and should be composed of macronutrients, micronutrients and also fibers. However, it is worth emphasizing the importance of individualizing the diet plan, adapting it to cultural, ethnic, psychosocial, economic and daily caloric needs. The total number of calories prescribed for children and adolescents with T1DM should be based on their nutritional status, age and level of physical activity, serving an amount sufficient to normalize blood glucose, avoid chronic and acute complications, besides promoting an improvement in the quality of life [4,6-8].

Considering the consequences that may arise from inadequate glycemic control, the objective of this study was to evaluate the influence of food consumption by children and adolescents with type 1 diabetes Mellitus on the glycemic profile.

\section{METHO D S}

Longitudinal observational study, conducted at the Pediatric Endocrinology Unit of a University Hospital. Inclusion criteria were: children and adolescents between 9 and 16 years of age, with T1DM for more than 6 months, using a basal-bolus insulin regimen, absence of comorbidities that would influence the glycemic response, signing of the Free and Informed Consent Form and the Free and Informed Assent. The study was approved by the Complexo Hospital de Clínicas da Universidade Federal do Paraná, Human Research Ethics Committee (CAAE: 44193214-7.0000.0096). The nutritional status was analyzed using the Z-score of the Body Mass Index (BMI) according to the classification proposed by the World Health Organization (WHO) [9].

The glycemic profile was assessed with a Continuous Interstitial Blood Glucose Monitor (CGM) (Guardian $\left.{ }^{\circledR}\right)$. The concept of "time in range" was used, which refers to the rate of total time in which the patient exhibited interstitial blood glucose values between 70 and $180 \mathrm{mg} / \mathrm{dL}$, "percentage of time in hyperglycemia" for values above $180 \mathrm{mg} / \mathrm{dL}$, and "percentage of time in hypoglycemia" whenever the monitor recorded values below $70 \mathrm{mg} / \mathrm{dL}$, during the 3-day follow-up [10]. Along with the glycemic profile, serum fasting $\mathrm{HbA} 1 \mathrm{c}$ data were analyzed by venipuncture, and was considered adequate when below $7.5 \%$ [11].

Food consumption was measured through a three-day diet record (Tuesday, Wednesday and Thursday); the quantitative analysis was performed using the NutriLife ${ }^{\circledR}$ diet analysis software [12]. A correction of the intra and interpersonal variability of the food records was also performed, using the Multiple Source Method $\left(\mathrm{MSM}^{\circledR}\right)$ software [13]. Food intake of macronutrients and fibers was classified as adequate or not, according to the ISPAD guideline [7]. Data were collected on carbohydrates whether counted or not.

Statistical analysis was performed using the Statistica ${ }^{\circledR}$ version 10 program [14]. The results were expressed as mean \pm standard deviation for continuous variables with symmetric distribution and median (minimum and maximum values) for those variables with asymmetric distribution. The 
estimation of the difference of continuous variables with symmetric distribution was assessed using the Student's t test, while for asymmetric variables the non-parametric Mann-Whitney test was used. Differences between categorical variables were assessed using Fischer's exact test, Pearson's chisquare test and the test for difference between proportions. To determine whether food consumption, carbohydrate counting and $\mathrm{HbA} 1 \mathrm{c}$ promoted changes in the glycemic profile, the multiple regression model was applied. A value of " $p$ " less than or equal to 0.05 was considered significant.

\section{R E S U L T S}

Out of the 34 children and adolescents with T1DM, 55.9\% were female, with a mean age of $13.6 \pm 2.1$ years and a diagnosis time of 6.1 years (1.2-14.6). Regarding the diagnosis of nutritional status, 76.4\% (26/34) were eutrophic, 18\% (6/34) were overweight and only $3 \%$ of the individuals were underweight, according to the BMI Z-score.

All individuals used the basal-bolus insulin regimen, $88.2 \%$ used Glargine+Ultra-fast and the rest Neutral Protamine Hagedorn and insulin regular, with an average insulin dose of $1.0 \pm 0.2 \mathrm{U} / \mathrm{kg} /$ day. Fifteen individuals (44.1\%) performed a carbohydrate count. The mean of $\mathrm{HbA} 1 \mathrm{c}$ was $9.7 \pm 1.5 \%$, with no difference between girls and boys $(p>0.05)$. Only 3 individuals exhibited an HbA1c below $7.5 \%$, as recommended by ISPAD [7].

Table 1 presents data on the total calories, proteins, lipids, carbohydrates and fibers consumption. Less protein consumption was observed among girls (19.1\% versus $23.7 \% ; p=0.001)$. Fiber consumption was on average $18.4 \pm 3.8 \mathrm{~g}$ and 12 individuals (35.3\%) showed adequate consumption.

Table 1. Description of total calories, macronutrient and fiber consumption in children and adolescents with type 1 diabetes Mellitus.

\begin{tabular}{lcc}
\hline Macronutrients & Median & \pm SD \\
\hline Total calories (Kcal) & 1789.7 & \pm 299.8 \\
Proteins & & \pm 29.1 \\
$\quad$ grams & 95.4 & \pm 4.3 \\
Lipids & 21.1 & \pm 15.2 \\
$\quad$ grams & & \pm 5.3 \\
$\quad$ Carbohydrate & 50.5 & \pm 42.3 \\
$\quad$ grams & 25.3 & \pm 5.8 \\
Fibers grams & & \pm 3.8 \\
\hline
\end{tabular}

Note: Note: \% of values based on total daily calories; SD: Standard Deviation.

Figure 1 shows the frequency distribution of the adequacy of the consumption of proteins, lipids, carbohydrates and the three macronutrients together. Among the 18 (52.9\%) individuals who presented with an inadequate protein consumption, all had an intake above the recommended diet. Regarding the consumption of lipids, only $2 / 22$ had a high consumption; the remaining (20/22) individuals had a low intake of this nutrient. The highest frequency of inadequate consumption was observed for carbohydrates $(p=0.07)$, with no significant difference, with $17 / 25$ individuals 
consuming above what was recommended and $8 / 25$ below. Only three individuals (3/34) exhibited adequate intake of all the macronutrients evaluated.

Hyperglycemia episodes were seen in all individuals with a mean of $61.3 \pm 18.5 \%$ of the time analyzed. In more than half the time rate reviewed the study population was hyperglycemic, with hypoglycemia being uncommon (Figure 2 ). This profile was similar between genders ( $p>0.05)$.

In the multiple regression model, all the metabolic and food intake variables were analyzed, to check which factors were associated with the variability of the rate of time in range; the carbohydrate count was selected as the variable responsible for $47 \%$ of the time rate

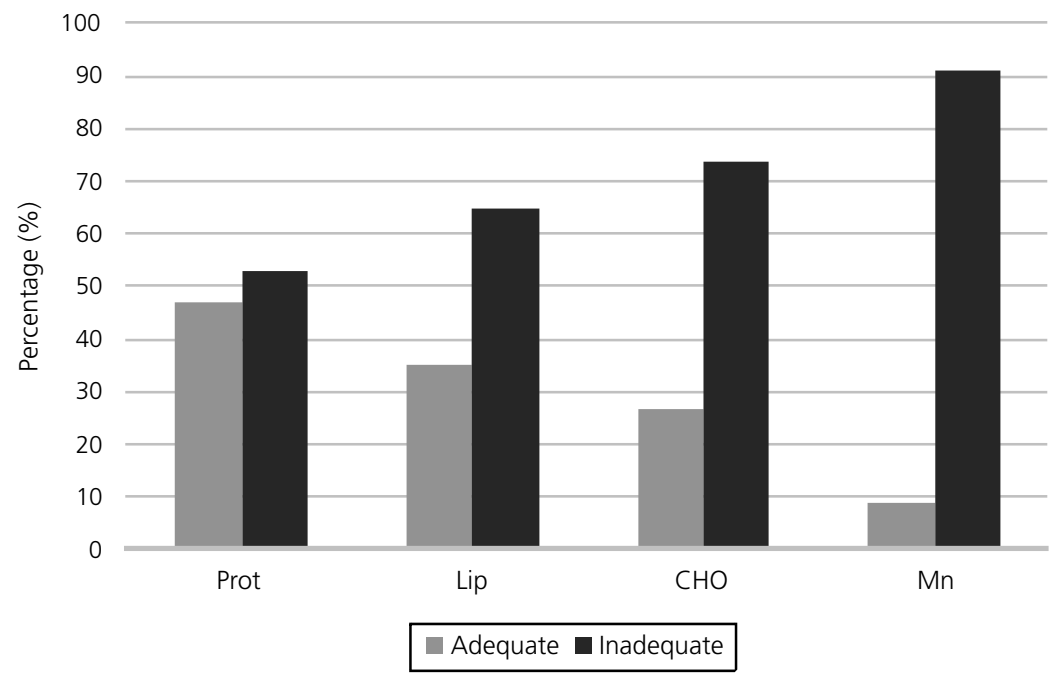

Figure 1. Distribution of adequate consumption of proteins, lipids, carbohydrates and the three macronutrients together in children and adolescents with type 1 diabetes Mellitus. Complexo Hospital de Clínicas da Universidade Federal do Paraná (PR), Brazil, 2018.

Note: CHO: Carbohydrates; Lip: Lipids; Mn: Three macronutrients together; Prot: Proteins.

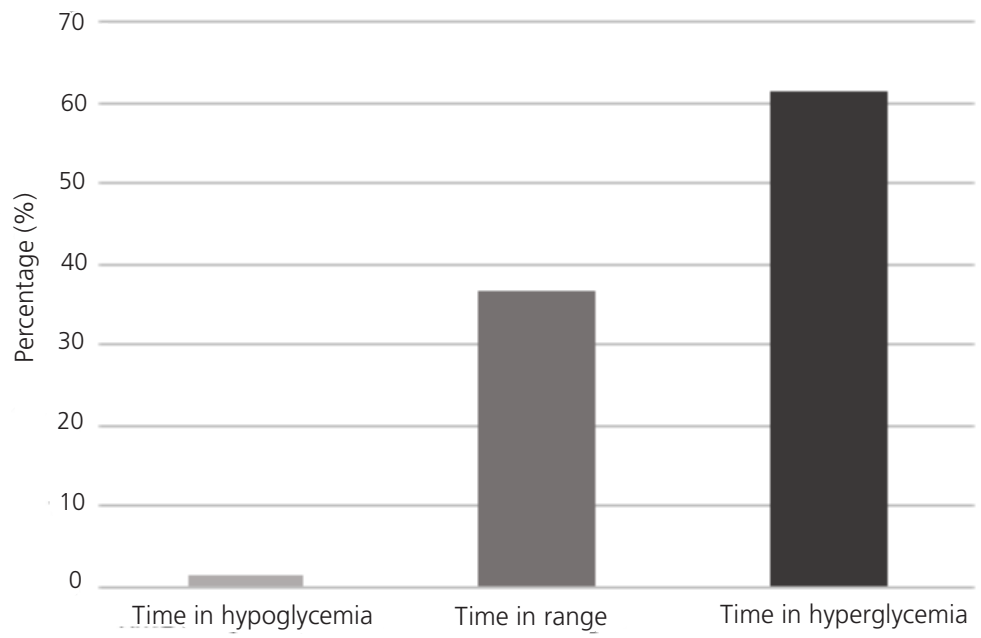

Figure 2. Profile of the glycemic control of children and adolescents with type 1 diabetes Mellitus. Complexo Hospital de Clínicas da Universidade Federal do Paraná (PR), Brazil, 2018. 
on range variability. By checking which factors were associated with the variability of the time rate in hyperglycemia, the carbohydrate count was selected as the variable responsible for $51 \%$ of the time rate in hyperglycemia variability. It is estimated that using the carbohydrate count the probability of maintaining the percentage of time in range $>40 \%$ is $65 \%$, as shown in Figure 3 (univariate logistic regression: $p<0.001$ ).

It is estimated that using the carbohydrate count the probability of maintaining the time rate in hyperglycemia $<50 \%$ is $75 \%$, as shown in Figure 4 (univariate logistic regression: $p<0.001$ ).

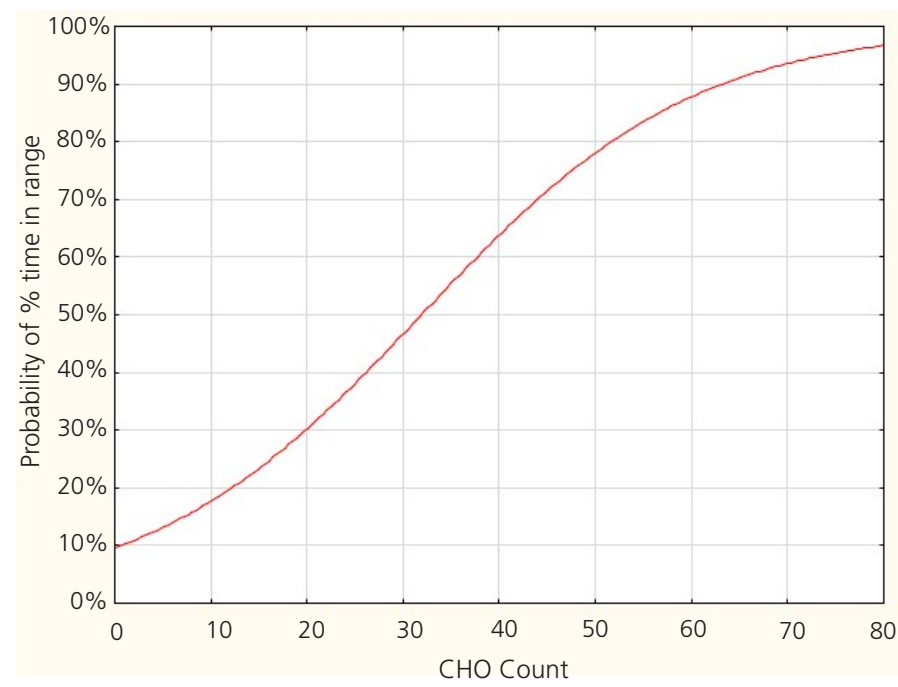

Figure 3. Probability of time in range according to carbohydrate count in children and adolescents with type 1 diabetes Mellitus. Complexo Hospital de Clínicas da Universidade Federal do Paraná (PR), Brazil, 2018. Note: Univariate Logistic Regression: $p<0.001$; CHO: Carbohydrate.

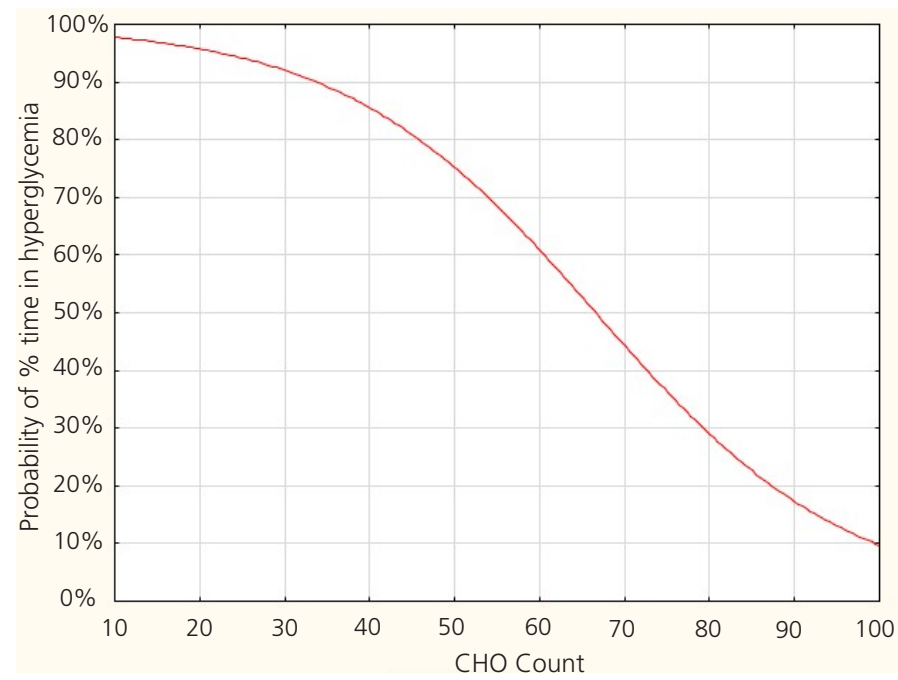

Figure 4. Probability of time in hyperglycemia according to carbohydrate count in children and adolescents with type 1 diabetes Mellitus. Complexo Hospital de Clínicas da Universidade Federal do Paraná (PR), Brazil, 2018.

Note: Logistic Regression: $p<0.001$; CHO: Carbohydrate. 


\section{DISCUSSION}

A balanced diet is essential in the treatment of patients with T1DM. However, this study faced a different reality from the one expected; most children and adolescents were not on an adequate diet, as recommended by ISPAD. Nansel et al. [15], and Seckold et al. [16] reports that young people with T1DM exhibit a low consumption of fruits, vegetables and whole grains, and an excess of refined grains and saturated fat. In a study carried out to assess the difficulties encountered in following T1DM therapy in adolescents, adhering to specific diets was one of the main barriers encountered as well as how to deal with the desire to consume foods common in diets of adolescents' without the disease, which are accessible in schools and public places [17].

Among the limitations of this investigation, the use of the food record for only three days of the week, without including the weekend should be underscored. It was decided not to evaluate the food record on weekends because the individuals would not use the continuous blood glucose monitor during this period. In addition, there were losses and lack of calibration of sensors. When the consumption of the macronutrients together was reviewed, only three individuals met the recommendations, a result similar to that found by Katz et al. [18], who analyzed the diet of 252 children and adolescents with T1DM and found that only $11.5 \%$ of the population consumed the adequate amount of all macronutrients.

Both American Diabetes Association and International Society for Pediatric and Adolescents Diabetes recommend fiber intake for all individuals with T1DM, due to fibers' ability to delay glucose absorption, contribute to glycemic control and significantly decrease HbA1c [19]. The guideline is to increase the consumption of foods such as fruits, vegetables and grains, to meet the need for fiber $[7,20,21]$. In the study population, only $35.3 \%$ were ingesting the necessary amount of fiber per day, with an average consumption of $18.4 \pm 3.8 \mathrm{~g}$, lower than that reported in other studies with children and adolescents with T1DM. Mosso et al. [22] found an average of $24.1 \mathrm{~g} /$ day, as well as Teles and Fornés [23], in which the reported average was 23.6 $\pm 7.8 \mathrm{~g} /$ day, for children and $27.9 \pm 14.0 \mathrm{~g} /$ day for adolescents. Studies carried out in the United States and Chile have shown that the average daily consumption of three servings of fruits and vegetables per day is not sufficient to meet the dietary recommendations; this information should be enhanced during nutritional consultations, informing the patient which foods and quantities they should consume to intake the amount of fiber required and to obtain the benefits of an improved glycemic control [15,22].

It was found that, despite the food consumption classified as inadequate, the majority of the study population was eutrophic (76.4\%) according to the BMI. Only $18.0 \%$ were classified as overweight, with a higher frequency in the female gender $(26.3 \%)$. These data are similar to those found by Silva et al. [24], who observed that among 38 adolescents with T1DM, 52.6\% had a normal BMI and only 5.3\% were overweight; the same results were found by Junior et al. [25], where among 77 adolescents with T1DM, 65 were eutrophic, six were overweight and six were obese.

It is known that intensive insulin therapy is the best choice for the treatment of T1DM, since it improves glycemic control and reduces the chronic complications of diabetes [17]. In this study population, all individuals used the basal-bolus regimen, with $88.2 \%$ using insulin analogues, a percentage above that found by Silva et al. [24] in which only $42.1 \%$ of participants combined insulin glargine with ultrafast insulin. The mean insulin dose was $1.0 \pm 0.2 \mathrm{U} / \mathrm{kg} / \mathrm{day}$, lower than that reported 
by Schwandt et al. [26] which was $1.9 \pm 0.64 U / \mathrm{kg} /$ day among 16 -year-old adolescent patients with unstable blood glucose level. It is important to note that the majority of the study population was composed of adolescents and, in adolescence, several factors interfere with metabolic control, requiring higher doses of insulin in most cases [27].

Although the majority of the population assessed used intensive insulin therapy, the number of children and adolescents with inadequate glycemic control assessed by the CGM, with episodes of hyperglycemia evident in all individuals, in more than half of the percentage of time analyzed was a condition that drew attention. Maia and Araújo [28] also found that 87 individuals with T1DM remained with a high glycemic average in almost $50.0 \%$ of the CGM record time. The time rate in which individuals had blood glucose levels within the recommended levels was only $36.6 \%$, which is below the recommended rate that should be 50.0 to $60.0 \%$ of the time. It is known that the longer this period, the better the metabolic control [6]. HbA1c was also above what is recommended $(9.7 \pm 1.5 \%)$, a fact that is in line with a Brazilian study carried out with 36 children and adolescents with T1DM, who had an average HbA1c of $9.48 \pm 2.22 \%$ [29]. During adolescence, there is a complex interaction between physiological, psychological and social factors that interfere with the metabolic control and low adherence to treatment that may be the cause of a high $\mathrm{HbA1c}$ [30].

The carbohydrate counting method is already a food planning tool that is safely proposed for all individuals with T1DM, as a number of studies has proven its influence in improving glycemic control [5,30-32]. A meta-analysis showed that HbA1c was significantly lower in individuals who performed carbohydrate counting [31]. In addition, the carbohydrate counting allows greater food flexibility for children and adolescents and an improvement in postprandial blood glucose, with a higher percentage of level values within range [31]. These benefits were also observed in this study.

\section{CONCLUSION}

It was concluded that most children and adolescents with T1DM are in an adequate nutritional status, but have an inadequate food intake of both macronutrients and fibers and an unsatisfactory glycemic control. The carbohydrate counting method, on the other hand, was beneficial and responsible for maintaining blood glucose for a greater percentage of time within range and a lower time rate for hyperglycemia, which enhances the importance of the method in the treatment and improvement of patients' glycemic control.

The importance of adequate food consumption for children and adolescents with T1DM and its benefits for an improved glycemic control makes it essential that more studies be carried out, in order to develop strategies to foster healthy eating to improve adherence to the recommendations and allow a better quality of life for these patients.

\section{CONTRIBUTORS}

CK FRITZ and S NESI-FRANÇA contributed with the conception and design, data analysis and interpretation, review and approval of the final version of the article. AAP LEÃO contributed whit data analysis and interpretation. MEMG DIAS and AAC DEMARTINI contributed with data analysis and interpretation, review and approval of the final version of the article. 


\section{RE FERENCES}

1. Benkhadra K, Alahdab F, Tamhane S, Wang Z, Prokop LJ, Hirsch IB, et al. Real-time continuous glucose monitoring in type 1 diabetes: a systematic review and individual patient data meta-analysis. Clin Endocrinol. 2016;86:354-60.

2. International Diabetes Federation. International Diabetes Atlas. 8th. ed. Brussels: Federation; 2017 [cited 2018 Dec 10]. Available from: https://www.idf.org/e-library/epidemiology-research/diabetes-atlas/134-idfdiabetes-atlas-8th-edition.html.

3. Tschiedel B, Puñales M. Tratamento do diabetes: abordagens farmacológicas e cirúrgicas. In: Diabetes na prática clínica: edição 2.0. São Paulo: Sociedade Brasileira de Diabetes; 2015 [citado 10 dez 2018]. Disponível em: https://www. diabetes.org.br/publico/destaques/1008-e-book-2-0

4. Egídio J, Oliveira P, Junior R, Vencio S. Diretrizes da Sociedade Brasileira de Diabetes 2017-2018. São Paulo: Clannad; 2017 [citado 10 dez 2018]. Disponível em: https://www.diabetes.org.br/profissionais/images/2017/ diretrizes/diretrizes-sbd-2017-2018.pdf

5. Vaz EC, Porfirio GJM, Nunes HRC, Nunes-Nogueira VDS. Effectiveness and safety of carbohydrate counting in the management of adult patients with type 1 diabetes mellitus: a systematic review and meta-analysis. Arch Endocrinol Metab. 2018;62(3):337-45.

6. Lottemberg AMP. Características da dieta nas diferentes fases da evolução do diabetes melito Tipo 1. Arq Bras Endrocrinol Metab. 2008;52:251-9.

7. Smart CE, Annan F, Higgins LA, Jelleryd E, Lopez M, Acerini CL. ISPAD Clinical Practice Consensus Guidelines 2018: nutritional management in children and adolescents with diabetes. Pediatr Diabetes. 2018;27:136-54.

8. Mańkiewicz-Zurawska I, Jarosz-Chobot P. Nutrition of children and adolescents with type 1 diabetes in the recommendations of the Mediterranean diet. Pediatr Endocrinol Diabetes Metab. 2019;25(2):74-80.

9. De Onis M, Onyango AW, Borghi E, Siyam A, Nishida C, Siekmann J. Development of a WHO growth reference for school: aged children and adolescents. Bull World Health Organ. 2007;85(9):660-7.

10. Danne T, Nimri R, Battelino T, Bergenstal RM, Close KL, DeVries JH, et al. International consensus on use of continuous glucose monitoring. Diabetes Care. 2017;40:1631-40.

11. Rewers MJ, Pillay K, Beaufort C, Craig ME, Hanas R, Acerini CL, et al. Assessment and monitoring of glycemic control in children and adolescents with diabetes. ISPAD Clinical Practice Consensus Guidelines 2014 Compendium. Pediatr Diabetes. 2014;15(20):102-14.

12. Nutrilife Software. Nutrilife diet analysis: software of Nutrition. Version 9.0 [software]. Maringá: Nutrilife Software de Nutrição; 2016 [citado 15 out 2018]. Disponível em: http://www.nutrilifesoftware.com.br/ netbook/setup.exe

13. German Institute of Human Nutrition Postdam-Rehbrucke. Multiple Source Method Progam. Version 1.0.1 [software]. 2008-2011 [cited 2018 Oct 30]. Available from:https://msm.dife.de

14. StatSoft. Statistica. Statistics progam. Version 10 [software]. 2010 [cited 2018 Nov 10]. Available from: www. statsoft.com

15. Nansel TR, Laffel LMB, Haynie DL, Mehta SN, Lipsky LM, Volkening LK, et al. Improving dietary quality in youth with type 1 diabetes: randomized clinical trial of a family-based behavioral intervention. Int J Behav Nutr Phys Act. 2015;12(58):1-11.

16. Seckold R, Howley P, King BR, Bell K, Smith A, Smart CE. Dietary intake and eating patterns of young children with type 1 diabetes achieving glycemic targets. Bmj Open Diabetes Res Care. 2019;7(1):1-7.

17. Pires M, Bani R, Lima G, Haddad MI, Takamoto P, Pires L, et al. Análise das dificuldades relacionadas ao seguimento de condutas terapêuticas do adolescente com diabetes mellitus tipo 1. J Human Growth Develop. 2016;26(1).

18. Katz ML, Mehta S, Nansel T, Quinn H, Lipsky LM, Laffel LM. Associations of nutrient intake with glycemic control in youth with type 1 diabetes: differences by insulin regimen. Diabetes Technol Ther. 2014;16(8):512-8.

19. Basu A, Alman AC, Snell-Bergeon JK. Dietary fiber intake and glycemic control: coronary artery calcification in type 1 diabetes (CACTI) study. Nutr J. 2019;18(23):2-8.

20. American Diabetes Association. Standards of medical care in diabetes. Diabetes Care. 2017;40(1):4-5.

21. Ahola AJ, Forsblom C, Groop PH. Adherence to special diets and its association with meeting the nutrient recommendations in individuals with type 1 diabetes. Acta Diabetol. 2018;55(8):843-51. 
22. Mosso C, Halabi V, Ortiz T, Hodgson MI. Dietary intake, body composition, and physical activity among toung patients with type 1. J Pediatr Endocr Met. 2015;28(7-8):895-902.

23. Teles SAS, Fornés NS. Consumo alimentar e controle metabólico em crianças e adolescentes portadores de diabetes melito tipo 1. Rev Paul Pediatr. 2011;29(3):378-84.

24. Silva ANS, Apolonio MS, Alcantara CM, Queiroz MVO. Características socioculturais e clínicas de adolescentes com diabetes mellitus tipo 1. Cogitare Enferm. 2016;21(4):1-8.

25. Junior RRL, Cardoso-Demartini AA, Ono AHA, Andrade, GC. Prevalência de obesidade em crianças e adolescentes com diabetes melito tipo 1. Rev Paul Pediatr. 2008;26(2):142-5.

26. Schwandt A, Hermann JM, Boettcher C, Dunstheimer D, Grulich-Henn J, Kuss O, et al. Longitudinal trajectories of metabolic control from childhood to young adulthood in type 1 diabetes from a large German/ Austrian registry: a group-based modeling approach. Diabetes Care. 2017;40:309-16.

27. Campos, RA. Insulinoterapia. Nasce Crescer. 2011;20(3):182-4.

28. Maia, FFR, Araújo LR. A Hipoglicemia silenciosa é parte do controle glicêmico ideal em pacientes com DM1? tempo de hipoglicemia pelo CGMS versus média glicêmica. Arq Bras Endocrinol Metabol. 2008;52(6):994-1000.

29. Duarte SV, Rajão JS, Pinho JF, Santos LM, Alves-Neves CM, Magalhães GS, et al. Changes in aortic pulse componentes, pulse pressure amplification, and hemodynamic parameters of children and adolescentes with type 1 diabetes. Clin Care Technol. 2018;20(2):202-9.

30. Plamper M, Gohlke B, Wõfle J, Konrad K, Rohrer T, Hofer S, et al. Interaction of pubertal development and metabolic control in adolescents with type 1 diabetes mellitus. J Diabetes Res. 2017. https://doi.org/10. $1155 / 2017 / 8615769$

31. Tascini G, Berioli MG, Cerquiglini L, Santi E, Mancini G, Rogari F, et al. Carbohydrate counting in children and adolescents with type 1 diabetes. Nutrients. 2018;20(1):109. https://doi.org/10.3390/nu10010109

32. Papakonstantinou E, Papavasiliou K, Maouri C, Magriplis E, Pappas S, Bousboulas S, et al. Postprandial glucose response after the consumption of three mixed meals based on the carbohydrate counting method in adults with type 1 diabetes: a randomized crossover trial. Clin Nutr. 2019;31:48-55. https://doi.org/10.1016/j. clnesp.2019.03.002

Receveid: October 22, 2019

Final version: April 24, 2020

Approved: October 9, 2020 